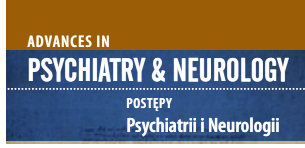

Correspondence to/Adres do korespondencji:

Beata J. Kasperek-Zimowska

Instytut Psychiatrii i Neurologii

ul. Sobieskiego 9

02-957 Warszawa, Polska

e-mail: zimowska@ipin.edu.pl

Submitted/Otrzymano: 25.11.2020

Accepted/Przyjęto do druku: 14.11.2021

\section{The specificity of the use of bibliotherapy as an element of psychiatric rehabilitation in a group of patients suffering from schizophrenia} Specyfika zastosowania biblioterapii w rehabilitacji psychiatrycznej chorych na schizofrenię

\author{
Beata J. Kasperek-Zimowska' (D), Agata Bednarek', \\ Marta Giguere', Wojciech Orłowski', Maryla Sawicka² (D)
}

'Institute of Psychiatry and Neurology, Warsaw, Poland

${ }^{2}$ The Maria Grzegorzewska University, Institute of Psychology, Warsaw, Poland

\begin{abstract}
Purpose: This article emphasizes the characteristics of the application of bibliotherapy in psychiatric rehabilitation of people suffering from chronic schizophrenia. The role of the bibliotherapist and methodology for conducting bibliotherapy for people with chronic schizophrenia are also described.

Views: The characteristic symptoms are connected to a patient's perception of the surrounding reality differing from the norm. This may be due to the symptoms of schizophrenia and its course, in which psychoticism can become a regulative part of a patient's personality. The academic definition of bibliotherapy proposed by Ewa Tomasik says that "bibliotherapy is an intentional activity that uses books or non-printed materials to fulfil rehabilitative, re-socializing, prophylactic and developmental aims for people from varying social backgrounds, in different age and with diverse needs". This article focuses on and discusses the structure and course of bibliotherapy sessions embedded in individual and group rehabilitation process. An additional goal is to explain bibliotherapy as an element of the entire system of rehabilitation and therapeutic interactions which has a therapeutic effect for this system, not only in terms of individual classes. Attention is paid to the narrative nature of bibliotherapy, in combination with behavioral-cognitive, humanistic and psychodynamic interactions.

Conclusions: Bibliotherapy can help people suffering from chronic schizophrenia to organize their self-narrative and narratives about other people, to make them real and to organize their statements, so that the content and manner of thinking can be regulated.

Key words: bibliotherapy, schizophrenia, psychiatric rehabilitation.
\end{abstract}

\title{
Streszczenie
}

Cel: W artykule opisano specyfikę zastosowania biblioterapii w ramach oddziaływań rehabilitacyjno-terapeutycznych u pacjentów chorujących na przewlekłą schizofrenię.

Poglądy: Naukowa definicja biblioterapii wg Ewy Tomasik mówi, że „biblioterapia jest zamierzonym działaniem przy wykorzystaniu książki lub materiałów niedrukowanych do realizacji celów rewalidacyjnych, resocjalizacyjnych, profilaktycznych oraz ogólnorozwojowych" osób o różnym pochodzeniu społecznym i w różnym wieku oraz z różnymi potrzebami czy chorobami. Definicja podkreśla także, że „koniecznym elementem jest międzyosobowy kontakt indywidualny lub też grupowy z biblioterapeutą”. Zakłada i wyróżnia wagę kontaktu z biblioterapeutą, który wybiera literaturę, podąża za słuchaczami i jest wrażliwy na istotne wątki, które poruszają grupę słuchaczy. Biblioterapia została opisana szczególnie w odniesieniu do budowania tożsamości pacjentów, a także takich objawów choroby, jak urojenia czy formalne zaburzenia myślenia. Owa specyfika odnosi się do innego odbioru otaczającej rzeczywistości przez pacjentów oraz samych siebie. Może to wynikać z objawów choroby i jej przebiegu, gdzie "psychotyzm” może stać się częścią osobowości pacjenta i jej regulatorem. Opisano przebieg i strukturę sesji biblioterapeutycznych w połączeniu z całym indywidualnym i grupowym procesem rehabilitacji, co stanowi podstawowy cel artykułu. Została opisana także rola i sposób zaangażowania biblioterapeuty w prowadzenie biblioterapii dla osób chorujących na przewlekłą schizofrenię. Zwrócono uwagę na narracyjny charakter biblioterapii w połączeniu z oddziaływaniami behawioralno-poznawczymi, humanistycznymi i elementami psychodynamicznymi. 
The specificity of the use of bibliotherapy as an element of psychiatric rehabilitation in a group of patients suffering from schizophrenia specyfika zastosowania biblioterapii w rehabilitacji psychiatrycznej chorych na schizofrenię

Wnioski: Biblioterapia może pomóc osobom cierpiącym na przewlekłą schizofrenię w porządkowaniu autonarracji i narracji o innych ludziach, urealnianiu jej, a także porządkowaniu własnych wypowiedzi. Może więc regulować treść myślenia i tok myślenia.

Słowa kluczowe: biblioterapia, schizofrenia, rehabilitacja psychiatryczna.

\section{INTRODUCTION}

Bibliotherapy, in the simplest terms, is therapy through storytelling. The fundamental features of this method are written stories and the use of the narrative properties of the human mind - thoughts are articulated with words connected to each other according to the grammatical rules of a certain language. We build the narrative about ourselves or others by using words, which can be either said or written, giving them a grammatical structure, including in the form of a story. Stories include information about specific experiences (emotions, feelings) and perceptions of the world. Most people like listening to stories, engaging with them across the stages of the life course, which makes this therapeutic method universally applicable. Of particular therapeutic value are the kind of stories that show the character of interpersonal relations and depict inner conflicts, thereby becoming a cognitive base or a mirror of the recipient's own experiences. They constitute the source of new ideas helping to resolve different problems, additionally developing social integration by showing that other people struggle with similar issues. By reading aloud or telling specific stories it is possible to help with a variety of emotionally difficult situations, such as fear of making a decision, coping with a failure, or death of someone very important, just by providing an emotional connection to other people's lives.

Ewa Tomasik's definition of bibliotherapy states that "bibliotherapy is an intentional activity that uses books or non-printed materials to fulfil rehabilitative, re-socializing, prophylactic and developmental aims" for people from varied social backgrounds, in different age in different age and with diverse needs [1]. Tomasik's definition also points out that "interpersonal contact with the bibliotherapist, either individual or in a group form, is a necessary part" of this method. This definition emphasizes the helpfulness of storytelling in various therapeutic and educational settings. It also assumes and stresses the importance of the contact with a bibliotherapist, who chooses the literature, follows their audience and is sensitive to important topics which relate to the concerns of the group. Bibliotherapy is also applicable in psychiatric rehabilitation as a form of therapy, among others, for people suffering from chronic schizophrenia; here the individual and group work on an emotional reference-base in the form of a written text, which a patient to come back to and re-read. These people cope with their emotions and internal conflicts by using defensive mechanisms such as splitting, projective identification or delusions. Some patients manifest a delusional readiness caused by subconscious fear of being soaked, or are afraid that someone/something may encroach on their self [2]. The participant may feel proud and pleased to be open to the group, and quickly become afraid that they are taking up too much time with their speech. This, in turn, makes the patient feel that the other participants have a hostile attitude towards them. Story- and group-activities focused on emotions and internal conflicts inside the group can decrease the intensity of defense mechanisms by releasing the emotional load in a secure atmosphere, or in individual contact with a therapist after a session.

The characteristics of the application of bibliotherapy in psychiatric rehabilitation for people suffering from chronic schizophrenia particularly concern, apart from the content helpful for many people, the different perception of the surrounding reality and vision of themselves that are caused by symptoms of the disease and its course, in which "psychoticism" may become a part of the patient's personality and its dysfunctional regulator. Thus, bibliotherapy can help in organizing auto-narration and narration about other people, making it more real and functional (patients begin considering different possible versions of events, identifying the motivations of others), while also helping them organize for themselves the statements of others'.

\section{THE THERAPEUTIC FUNCTION OF LITERATURE}

Literature provides a variety of content, contains the experience and knowledge of the author, and is often based on imagination. It can trigger emotional experiences, and thus help readers to construct and order of their own knowledge and self-knowledge, thereby helping to build the cognitive representation of the world and oneself. Thanks to this property of literature, patients suffering from schizophrenia can regulate their own cognitive processes, focus their attention on the text, relate content to themselves, and improve the expression of their own thoughts.

The therapeutic role of the book is achieved by helping the patient to become aware of their own emotional experiences and to have access to them. This happens thanks to the metaphors and symbols contained in the text that trigger personal emotions. Becoming aware of emotional 
experiences influences the regulation of emotions among patients, reducing mental tension. Bruno Bettelheim pointed to another function of literature, which is its compensatory role: it stimulates dreams that have a substitutive function and can satisfy unmet needs and postpone the desire for immediate gratification, which for people who are mentally ill can be a safe space to express their own needs [3].

Literature is a special kind of art that makes a person refer content to themselves. Self-creation consists not only in including personal experience, but also the experience of others, which is included in the narration. Using psychodynamic language, literature is based on the introduction of content that includes the emotions aroused by the presence of an imaginary object. The reflection/ insight arising during the engagement with literature can cause important content to be verified, resulting in strong emotions that can lead to catharsis. The process of interpreting previous emotions and gaining an insightful understanding of the problem can cause, together, tension reduction. This is particularly important for people with a psychotic personality structure, for their own or other people's emotions are dangerous. Experience through literature does not necessarily lead to the solution of individual problems, but rather enables the understanding of personal problems and experiences, and this can be the beginning of changes leading to self-acceptance.

The person perceiving the story experiences the characters, which also fosters social learning through imitation, modelling and identification. He evaluates the characters from different points of view, depending on his own past and experience of a character's story. If he encounters a different point of view, he can safely discuss and accept it internally. A person with a stronger self is more focused on the author's message and arguments, which can become his inner voices, important in developing a new understanding or reinterpretation of himself. On the other hand, people with a weaker self may identify with or blend in with the protagonist's self. This group includes mostly patients diagnosed with schizophrenia. The role of the therapist is to help separate their own content from external content by directly naming the patient's experiences.

Initially, human behaviour is regulated by innate mechanisms, mainly of an emotional nature. Later on, conscious cognitive processes are increasingly involved in self-management. However, emotional chaos, which occurs when strong emotions dominate, hinders rational action. An outburst of psychosis can be seen as a disintegration of controlling cognitive processes over emotions and behaviour, and work in the bibliotherapeutic process is an attempt to synthesize these processes.

Bibliotherapy, as mentioned above, involves among other things the modification of thinking, elimination of dysfunctional beliefs, and introduction of new ones which do not cause negative effects. Thinking is restruc- tured by providing arguments for the rejection irrational, defective beliefs.

Human emotions, aspirations and feelings, especially unconscious ones, influence a person's life. Fables, myths and stories provided meaning and created the human mind by verbalizing, and thus establishing an awareness of, people's awareness of their desires, aspirations and fears. They provided for the conscious control of thinking over the emotions, allowing the latter to be regulated, and behaviour controlled, which is of particular importance in therapeutic work with patients suffering from schizophrenia due to the weakening of their cognitive processes. Mythological stories are a reflection of the human psyche, the dilemmas we face, a guide in searching for answers to the fundamental questions and problems of human existence: Who am I? Where do I come from? Where do I go? Is death the ultimate end of life? What is good and what is bad?

\section{BIBLIOTHERAPY CLASSES IN PSYCHIATRIC DAY REHABILITATION UNIT}

Bibliotherapy was included in the rehabilitation program of the Day Rehabilitation Unit at the Institute of Psychiatry and Neurology, Warsaw in August 2012 to enrich the provision of therapy for patients suffering from schizophrenia. Classes are voluntary, take place once a week, last 60 minutes, and take the form of an open discussion group consisting of 15-20 people. The group determines and follows the principles of the meetings: the rule of confidentiality, and respect for others and their comments. The basic materials used during the course are a board, art supplies, and pictures of participants in order to stimulate the discussion, understand and deepen the subject matter. A starting point is a literary text concerning a chosen subject related to the topic to be discussed. In the ward a clinical approach to bibliotherapy (according to Rubin) is used. It is dedicated to patients with emotional or behavioural problems, and its main aim is to generate insights and alter patients' psychological situations, including thinking disorders [4].

Among the many things bibliotherapy is used for during the work with a patient, the following are the most important: to mentalize experiences coming from the person receiving the story being read and from other participants; emotional experience - experiencing feelings inaccessible to consciousness; motivating patients read as a qualitative form of occupying free time with valuable content, creating a sense of commonality during emotional experiences; establishing awareness and a greater acceptance of otherness; rehabilitation of thinking processes and the verbal expression of thought; and creating a space for the safe expression of and reflection on topics discussed and different opinions. 
The specificity of the use of bibliotherapy as an element of psychiatric rehabilitation in a group of patients suffering from schizophrenia specyfika zastosowania biblioterapii w rehabilitacji psychiatrycznej chorych na schizofrenię

\section{AGENDA}

As mentioned above, a starting point of a discussion is a literary text concerning a chosen subject related to the debate. It can also be a movie, or family pictures, sketches, songs or poems. It is important that topics do not include the sickness (schizophrenia) itself - other therapeutic classes e.g. psychoeducation, training oriented towards the control of symptoms, and treatment training already engage this area. There are, however, exceptional situations in which reference to psychosis and its consequences in the lives of patients is not avoided. This happens when patients clearly introduce the topic of the disease into the class topic. Attention should be paid to the relevant content that is omitted in other classes due to the focus on the symptoms of the disease. This often overlooked content concerns emotional life, internal conflicts and identity.

Bibliotherapy sessions engage with topics such as inner resources, relations with close people, experienced emotions, feelings, dreams and needs, readiness to accept social roles, growing up, memory, plans and life changes, making important decisions, love, enjoying life, ageing and death.

Attentiveness is one of the very important qualities a bibliotherapist uses to monitor the discussion of the subject in a class. In a bibliotherapist's work it is not only important to follow the group, but also (due to positive symptoms) to make sure the main thread of the discussion is returned to. The sessions are not pre-planned, but each session needs to be prepared, according to the patients' needs - the topic is usually continued from the previous session. The session starts with the collection of information from the participants; they are also asked if there is anything stirring happening. The way books, poems, limericks, fairy tales, movies, or pictures from a specific stage of life are chosen originates from a topic discussed during the classes and patients' curiosity. If the participants do not raise any issue, the topic can also be suggested by the bibliotherapist.

The customary progress of a bibliotherapy session runs as follows:

1) greeting, introductory chat;

2) quick review of content from a previous session: materials read, collection of reflections and associations generated by the class or that arose during the previous week;

3) presentation of new material;

4) discussion according to the afore-mentioned rules;

5) close;

6) after the session has ended: collection of topics for the next session, literature selection;

7) example of discussed subjects and bibliotherapy's process.

\section{SAMPLE SUBJECT AND STRUCTURE OF THE BIBLIOTHERAPY PROCESS}

Fifteen classes began with a selection from the book "The Secret Diary", written by Hendrik Groen [5]. The book points out that it is possible to enjoy life independently of a given situation - no matter how tough things are there is always a bright side. This inclines people to think about their own death, the end of life, and how to manage to enjoy life, and whether it is better to not engage and wait with anxiety for life to end, or to have a proactive attitude. Some of the participants noticed exactly this thread - one should try to enjoy life while it lasts and appreciate important people, or everyone whose lives one encounters. Others disagreed, arguing that in the Polish reality this is impossible due to financial issues (the main character in the book lives in a rest home in Denmark). On this basis a discussion arose and evolved into a question: does happiness depend on money, or does it stem from other things. At the end of the session the influence of other people on one's life was discussed.

In a later session a section of Irvin Yalom's book "Becoming myself" referred to this thread [6]. The book covers the subject of becoming oneself throughout a whole life until its end, showing how acceptance and experiences can be used to build and establish one's own identity. Identity is created during a whole lifespan, from early childhood to advanced old age. Different experiences poverty and rejection, but also positive changes like improvements in social status or quality of life, self-development and education, important people encountered on one's way - influence our identity and shape who we become. Consequently, the next fragment described such as above-mentioned issues. Patients recollected important people from their lives, especially parents, but also teachers and acquaintances from school. They agreed that it is impossible to create one's own identity without the influence of and emotional connections with other people. Feelings towards others and the pace of passing time which we can just spend with them convinced the bibliotherapist to choose a poem by Jan Twardowski, written in a direct way about the love for those who have already died, but also those who are still around.

The poem "Spieszmy się" ("Let us hurry") appeared to be very stirring for the group and encouraged everyone to take a part in the discussion. Many people underlined the point that it is not only necessary to appreciate relationships with others, to notice what they are currently bringing into our lives, but also to appreciate those people who are alive but with whom we no longer have contact for a number of reasons but whose presence permanently imprinted itself on us for various reasons. Participants often mentioned their parents, grandparents, friends from childhood, teachers. At the end of the session the topic of remembering and maintaining memories of others, and how enriching this can be, emerged. A relevant text describing this topic was a part of the book "Ostatnie rozdanie" ("Last Deal") by Wiesław Myśliwski [7].

The narrator reaches for his old diary in which over several decades he writes the names of different people, 
and by reading it again he gets his life together. Not only key people are significant, but also those who appear in life for a shorter time, sometimes even a moment, imprinting a trace on us and our personalities. Patients referred to people from different periods of their lives e.g. parents, people met during holidays on a beach, in hospital, forgotten playmates from earliest childhood. The topic of 'important people from the past' emerged from this session, so for a subsequent one patients brought pictures of important moments from their past.

The pictures showed patients with their friends and relations, their own role in the group from different stages of life. This session concluded with the bitter reflection that others distance themselves from patients because of their illness. A small number of people in the group said that maybe they also separate themselves because of the illness because they are ashamed, which result in the loss of social commitment. This, although topics related to the sickness are usually avoided, inclined a host to choose a fragment from Elyn Saks' book "The Center Cannot Hold: My Journey Through Madness" [8]. This selection describes the onset of a friendship which commenced after the main character fell ill with schizophrenia. It also shows the character and course of this friendship, including sincerity, emotional and intellectual openness (the essence of a true friendship), and separation and the maintenance of a good relationship at the same time (with one of the people involved moving house). The participants recollected and described lost relationships - those they struggled to maintain despite an illness, and other, newer ones formed in later times. At the end of this session one of participants asked if love in schizophrenia is possible.

The topic of loving someone and building a lasting relationship was of great interest to the group, hence a passage from the same book about love was chosen for the next meeting. The author describes her love for a man and her concerns about it. She becomes emotionally engaged and this relationship seems to be permanent, and ends in marriage. Participants reminisced about their own relationships, with singles expressing their longing for a romantic attachment, their fear of not finding anyone who can feel affection for them, and their uncertainty about being able to reciprocate love. This subject turned out to be tough, and possibly for this reason the discussion broadened out to include love for people and nature.

Because of this, and it being early spring outside, the next choice was a poem by Bolesław Leśmian. "Wiosna" ("Spring") is about admiration of the world and nature, and about the fact that many springs pass by - so about the transience of life. Participants talked about the beauty of nature, how it calms them down and how one can delight in it. Some pointed out that life passes and that different fears can be dealt with through a commitment to faith. This revealed the important theme of fear of death, and the taming of it. Some patients noticed that commitment to religion is also possible, so this time as materials for classes some pictures of a trip to Medjugorje made by one of patients were used. For her, faith was the best way of coping with the fear of death and gave her strength in the daily struggle with various difficulties. The participant presented the photos, emphasized how important faith is for her and how much strength it gives her. The group referred to the topic using their own experiences. Some people drew strength from who they were (from their own identity and life experiences); faith was not a basis for building everyone's own identity.

Hence, the choice of material for the next session accurately reflected Krzysztof Kieślowski’s film "Gadające Głowy" ("Talking Heads"). People of different ages (children, youth, adults, elders) answer the director's question about who they are. The attendees contemplated who they are now, if and how their identity has changed and been enriched throughout their lives. They did not identify themselves with being a sick person, being a patient. The core of identity was being a daughter/son, a parent, a woman/man, a Catholic, a Pole. At the end of the session the patients came to the conclusion that the way their parents brought them up had a major influence on their personalities.

The next session was based on fragment from the book "Nela i Artur. Koncert intymny Rubinsteinów” („Nela and Artur. The Rubensteins' Intimate Concert") [9], written by Ula Ryciak. It describes the way the Rubenstein parents raised their four children. The patients remembered and shared with the group how they were treated and brought up by their parents. They also talked about what kind of parents they became themselves (one of the participants survived the death of his own adult child). Some people were satisfied and grateful to their parents, some talked about painful experiences and some did not want to express themselves. Hence a discussion about being closed (distrustful, keeping secrets) or open emerged.

The next passage came from the book "Ucho igielne" ("The Needle's Eye") by Wiesław Myśliwski [10]. In the selected part the narrator describes his friend, who never said anything about himself, but who one day asked the narrator to introduce him to his parents. It was also known that the friend was gay. The patients shared their experiences about their friendships, about being honest and open to friendship or withdrawn, and keeping secrets or revealing information about themselves to others. There was a discussion of benefits, e.g. in terms of building and deepening bonds, and losses, e.g. when someone leaves because they find out that the person is mentally ill.

During the holiday season, participants choose and present their own material and form (passage from a book or movie, pictures etc.) according to their interests. One patient, for example, presented a section of the book "Kobiety, które walczą" ("Women who fight") by Sylwia 
The specificity of the use of bibliotherapy as an element of psychiatric rehabilitation in a group of patients suffering from schizophrenia specyfika zastosowania biblioterapii w rehabilitacji psychiatrycznej chorych na schizofrenię

Chutnik [11]. For her, perseverance and planning were important means of finding a goal for a given stage of life. She was trying to define herself and her own identity. Another person chose a fragment from the book "Noce i dnie" ("Days and nights") by Maria Dąbrowska [12]. She, similarly to the main character Barbara Niechcic, was concerned about a sense of life passing her by, and was afraid of loneliness. During the summer program, there were also slightly lighter topics such as the history of coffee or tea combined with the tasting of these drinks.

The above description, drawn from a series of fifteen sessions, illustrates how the threads emerge from one another, how the topic changes and how the bibliotherapist reacts to them (he follows the thread or directs the group's work accordingly). It also shows how the therapist guides the group work. He emphasizes the importance of the topic; when it is too difficult, he leads the group towards easier material, keeping important threads in mind. At the right time (when the group is ready) he returns to more difficult subjects. He is also a person who likes reading and is knowledgeable about new publications.

During the group sessions there were threads connected with personal identity, relationships with other people, fear of loneliness, the need to be loved and the fear of death. The participants shared their own experiences and reflected on their own point of view on fundamental existential issues by listening to different approaches, e.g. for some participants the meaning of life was faith, but there were also people for whom it made sense to be a good person or to focus on life in the moment, not to run out into the future or worry about the past. They could also confront their views and life attitudes in a safe atmosphere.

The observations show that most of the participants focused their attention on literary threads and related them to their lives. During the classes, participants became more and more open in their statements and related to the statements of others. In people who presented distracted thinking, there were attempts to organize their statements. The participants also asked each other questions aimed at mutual understanding.

The subject of bibliotherapy most often results from:

- participation in the therapeutic community, in which patients agree, including shifts and propose, for example, that the tearoom should be taken care of by a woman. Hence the topic of the female/male role, gender stereotypes. An article from the press on feminism was selected for bibliotherapy;

- group psychotherapy, during which one of the participants took up the topic of touch and love. She returned to this topic in bibliotherapy. Hence the selected poems about sensual love, e.g. poems by Leśmian;

- social situations in the ward, individual conversations with patients about the difficulties they report;

- changing seasons that affect some forms of activity in the ward, e.g. planning time off/going outside the ward.
At that time, the literature on the passing of time and changing seasons is selected;

- social situations in the world, in the media, "street talks", e.g. about refugees. Pictures of old, sick and homeless people were presented with the question "Who would you invite to your home?". Discussions of tolerance arise from this;

- poems and fairy tales about human qualities (vices and virtues) often work well as they consist in universal themes ("Define yourself, choose a poem, the character that describes you best");

- during the holidays, patients often choose how to live, perhaps due to a looser structure of activities in the ward.

\section{EXAMPLES OF THE IMPACT OF BIBLIOTHERAPY ON PARTICIPANTS}

Mrs. Gienia - returned to the past, referred to the content of her psychosis, in which the figure of an important teacher appeared; she gained insight into the symptoms (an excerpt from the "Society of Dead Poets" by N. Kleinbaum was presented to her).

Mrs. Adela - talked about the family home, parrots, music school, lost happiness, spoke fluently with positive emotions, where usually she was reticent and unfocused (L. Staff's poem "Childhood" was presented).

Mr. Maciej - participated in conversations about a worldview contrary to his confession, although he had previously left classes when he heard about a different worldview (an excerpt from the book by O. Tokarczuk "The Books of Jacob" was presented).

Mr. Alfred - initially avoided taking part in the classes, saw "faces laughing at him" in a large group. During the pandemic, the groups were reduced in size and then the patient began to talk much more about himself.

Mrs. Otylia - usually sleepy and absent, she "woke up" under the influence of literature, and quoted poems from memory.

\section{CHRONIC SCHIZOPHRENIA AND THE HEALING QUALITY OF STORYTELLING IN THOUGHT-DISORDER TREATMENT}

One of the symptoms of schizophrenia may be a particular challenge to therapeutic work, i.e. thought disorder. This is a specific sphere of human functioning, which allows one to create an assessment of oneself, other people and the world and to operate according to the information obtained from these areas. In a normative way one can think about oneself, that he is for instance a good person, but in a delusional way one can think of himself as being possessed by a devil and condemned to eternal damnation. Thought disorder [13] can cause affective disorder and behavioral/functioning disorder. Bibliother- 
apy's influence on a patient's emotions can, to a certain extent, normalize them, having an impact on functioning and interpersonal relations.

Typically in schizophrenia, thought disorder, inappropriate emotional agitation and reality misperception can together create a distorted picture of reality. A common aspect of this - observed among almost all patients - is a tendency towards delusional thinking. Inaccurate and unverified convictions/beliefs about reality become established and fossilized, although in the course of the disease an insight which allows a patient to cognitively identify his thoughts as delusions, can appear; but if these insights appear together with emotions the patient will still act in accordance with their 'fictional' ideas. Hence an important aspect of therapeutic work is the normalization of emotional experiences.

The most characteristic delusions are those of control (also called delusions of influence), i.e. external influences on the patient, his body and psyche, or the opposite - the patient's influence on his surroundings, psyche and other people's thoughts. Delusions of reference are also commonly observed. Patients discover significant connections between themselves and innocuous/mere facts or events. This may be related to their difficulty with separating themselves from the world [14] and the knowledge and consciousness related to their personal identity, which constitutes a core of a human development throughout a whole lifespan. It may deprive a person of independence in creating their own self [15]. Usually the delusional content is related to the patient's biography, based on a traumatic experience, conflictual relations with parents, first loves, the births of children, losses of important people or opportunities, deaths of loved ones etc. Delusions create the central point around which the patient builds his identity.

Commonly, the largest and most significant aspect of delusional symptoms is a deep impairment of the boundaries between elements of the patient's self (psyche and body) and environment, a weakness in or lack of a sense of the creation of personal mental processes and behaviours, and their own integrity and identity. Bibliotherapy can to some extent help identify a patient's own identity and the limits of their ego.

Also characteristic are delusions consisting in inappropriate understandings of other peoples' identities, or a conviction about a change in the patient's own identity. The content of delusions can be extremely extensive - there is no topic which cannot form the essence of a paranoid judgment. Schizophrenic delusions have a specific structure, called paranoid, to wit: they are weakly connected to each other logically, and they are accompanied by a sense of fundamental world transformation and an aura of mystery. Delusions are often directly related to the person experiencing them [16]. This area is particularly susceptible to bibliotherapy's in- fluence. As already mentioned, the content of delusions is often related to a patient's biography. This can be illustrated by the example of a patient for whom the loss of a baby (miscarriage) resulted in her thinking, first, that she was pregnant with many children, and then that she was giving birth to various animals. The longing to create a family caused her to believe that she had her own family. Texts about the loss of an opportunity to become a mother, or about the death of children, can connect to a patient's difficult experiences and facilitate the emergence of emotional insights.

A second domain of thought disorder is that of anomalies within their form, that is formal disturbances of the structure and the train of thoughts. A specific group consists in absent-mindedness' - variety of inconsistent statements, losing thought threads and following associations, that are unexpected for the audience, and an even higher level of thinking disintegration in which threads and thoughts become muddled. Also characteristic here is distance from the real aspects of the world (dereism) and less effective thinking. In bibliotherapy, a story's narrative helps the patient to concentrate their thinking on a quoted thread and store it in their short term memory, so that personal experiences can be referred to it. This requires a patient to analyse the memory, to recollect and name his experience out of it (extracting information from long-term memory). In the therapeutic process, logic and fluency during the selection of narrative thread, support of a patient's comments, and the maintenance of adequate topic development are main aims coordinated by the bibliotherapist. This approach can, in some ways, have a corrective effect on some formal thought disorders, e.g. for a patient encompassing multiple topics and losing the main thread in her statement, while in a broader view a main topic is noticeable but dispersed throughout a whole discussion. The therapist's role mainly consists in listening and selecting the major threads related to the main topic, followed by asking the patient questions to determine whether or not she has said exactly what she wanted to say (the "puzzle for the therapist").

Individual therapeutic work happens as part of a whole system of rehabilitation in which influences are chosen with a patient, or sometimes their family, but always in agreement with him and in accordance with his needs.

\section{PSYCHIATRIC REHABILITATION AS A THERAPEUTIC AND TREATMENT SYSTEM CONTAINING BIBLIOTHERAPY}

Due to its abundance of symptoms, causes, course and epidemiology schizophrenia is treated systematically/comprehensively. There are treatment standards agreed for it. Their base consists of pharmacotherapy consolidated with psychosocial methods such as involvements in a therapeu- 
tic community, psychotherapy, psychoeducation, occupational therapy, social-ability training, choreotherapy and therapy with psychoeducation dedicated patients' families. Bibliotherapy, when present in this interaction system, constitutes a separate therapeutic form. It is a result, among other things, of the way in which the subjects for the workshops are chosen and of the work on matters arising from the engagement with patients. A specific bibliotherapy topic, e.g. creating one's own identity along the lifespan, consisting in learning from contacts with others, that induces patients to reflect and draw conclusions about creating their own identity, dictates the content of further discussions, e.g. about the influence of significant people on patients' lives, ways of upbringing etc. This helps patients to organize experience and memories, and gives them a chance to see some things from a different perspective. Unlike structured interactions (social skills training), topics in the bibliotherapeutic process emerge spontaneously (they are not imposed by the bibliotherapist, although there are exceptions). The basis of the work is to persuade participants to "philosophize".

A patient attending this form of treatment benefits from the influence of various forms of interaction, beginning with the therapeutic community, through group psychotherapy and ending with individual psychotherapy. The therapeutic community allows for the definition of rights and obligations, roles in the community and the scope of influence on the group [17]. Social skills training provides an opportunity to improve or learn such capabilities as establishing and maintaining contact with others, managing an illness (e.g. how to identify and react to a relapse) [18], taking medicines [19], maintaining personal hygiene, and managing a domestic budget. Social- and neuro-cognition training helps to enhance mentalization skills and cognitive abilities [20, 21]. Positive therapy gives the patient a chance to discover and develop strengths, thanks to which they can derive pleasure from life, to learn how to savor things, pay attention to and remember good situations in daily life, and also to recognize positives in tough ones [22, 23]. Choreotherapy allows a patient to realize the physical limits of and the space occupied by a body, how it can be used in communication, what provides a pleasure in a body movement and what is difficult [24].

Psychoeducation activates discussions related to the illness across an entire spectrum: starting from its origins, through its course and groups of symptom, ending with treatment and one's own attitude to the sickness [25]. Group psychotherapy complements the whole rehabilitation process by giving the patient an opportunity to experience how a group process works, how they are perceived by others, what they can contribute to the group, and if they can open up to it. Access to all of these therapeutic forms allows for the identification of those which are the most beneficial for each individual and help them to enhance their social skills.

In psychiatric rehabilitation the sum of the different methods, i.e. training, psychoeducation, pharmacotherapy, as well as individual contact with the therapeutic, psychotherapeutic and bibliotherapeutic work described here, work together in an integrated way [26-28]. Methods are selected in such a way that they can be optimally adapted to patients in the psychiatric day ward.

\section{CONCLUSIONS}

The aim of the article was first of all to show the specificity of applying the process of bibliotherapy in a group of patients with schizophrenia and to describe the course of bibliotherapeutic activities.

The specificity of the application of bibliotherapy in psychiatric rehabilitation is based on its narrative character (the human mind works in a narrative way) and in relation to people with chronic psychosis it can also organize this narration, in a certain way repairing it [29]. It allows us to combine various auto-narrative threads, describing other people and the surrounding world in such a way that the patient can safely move around in it. It can also improve the way of thinking and consequently expressing one's own opinions. It is a field in which participants get to know each other, their views, reveal their emotions and support each other. The bibliotherapist conducts the process, taking into account the needs of the participants, their defense mechanisms and readiness to face a given problem. He uses the potential of the group to help individual participants.

This specificity also applies to the use of various therapeutic approaches, including the behavioral-cognitive, psychodynamic and humanistic. In practice, the therapist works in the areas of the above-mentioned theories. These interactions have been presented as part of the entire sphere of rehabilitation interactions in order to demonstrate the fact that it is not the bibliotherapeutic process itself that has a therapeutic effect, but the entire rehabilitation process. 


\section{Conflict of interest/Konflikt interesu}

Absent./Nie występuje.

Financial support/Finansowanie

Absent./Nie występuje.

\section{References/Piśmiennicłwo}

1. Tomasik E. Czytelnictwo i biblioterapia w pedagogice specjalnej. Warszawa: Wyższa Szkoła Pedagogiki Specjalnej im. Marii Grzegorzewskiej; 1994.

2. Prot K, Murawiec S. Psychodynamiczna terapia pacjentów psychotycznych w warunkach środowiskowych. Psychoterapia 2013; 4: 29-39.

3. Bettelheim B. Cudowne i pożyteczne. O znaczeniach i wartościach baśni. Warszawa: WAB; 2010.

4. Rubin R. Bibliotherapy sourcebook. London: Oryx Press; 1978.

5. Groen H. Małe eksperymenty ze szczęściem. Sekretny pamiętnik Hendrika Groena, lat 83 i 1/4. Warszawa: Albatros; 2016.

6. Yalom ID. Stając się sobą. Pamiętnik psychiatry. Warszawa: Czarna Owca; 2018.

7. Myśliwski W. Ostatnie rozdanie. Kraków: Znak; 2019.

8. Saks ER. Schizofrenia. Moja droga przez szaleństwo. Wrocław: Burda Media Polska; 2014.

9. Ryciak U. Nela i Artur. Koncert intymny Rubinsteinów. Warszawa: Agora; 2018.

10. Myśliwski W. Ucho igielne. Kraków: Społeczny Instytut Wydawniczy Znak; 2018.

11. Chutnik S. Kobiety, które walczą. Warszawa: WAB; 2017.

12. Dąbrowska M. Noce i dnie. Tom 1-4. Warszawa: Instytut Badań Literackich PAN; 2014.

13. Rybakowski J, Pużyński S, Wciórka J (eds.). Psychiatria. Tom 1. Podstawy Psychiatrii. Wrocław: Elsvier Urban \& Partner; 2010, p. 327-338.

14. Rosenfeld H. Impas i interpretacja. Tranls. Petryczko-Pater B, Kalita L. Gdańsk: Wydawnictwo Imago; 2012.

15. Schneider K. Clinical Psychopathology. New York: Grune and Stratton; 1959.

16. Krupa A, Styła R. Specyfika psychoterapii psychodynamicznej skierowanej do osób z rozpoznaniem schizofrenii. Badania jakościowe oparte na wywiadach z terapeutami. Psychiatria 2015; 12(3): 119-127.

17. Pawłowska B, Kiecka-Fijałkowska P, Potembska E, Domański M, Lewczuk E. Zmiany w zakresie funkcjonowania psychospołecznego u pacjentów objętych rehabilitacją psychiatryczną. Psychiatr Pol 2015; 49: 1191-1202.

18. Spiridonow K, Kasperek B, Chądzyńska M, Meder J. Nabywanie wiadomości na temat rozwiazywania problemów związanych $\mathrm{z}$ chorobą - porównanie metody treningu behawioralnego i psychoedukacji w grupie osób chorych na schizofrenię. Post Psychiatr Neurol 2002; 11: 371-381.

19. Meder J, Kasperek B, Spiridonow K. Ocena efektów zastosowania treningu „Powrót do społeczeństwa” w rehabilitacji chorych na schizofrenię leczonych lekami przeciwpsychotycznymi I i II generacji. Post Psychiatr Neurol 2003; 12: 45-53.

20. Kucharska K, Wilkos E, Sawicka M. Trening społecznego poznania i neuropoznania. Podręcznik terapeuty. Warszawa: Instytut Psychiatrii i Neurologii; 2013.

21. Farmasi L, Kiss A, Szendi I. The Narrative Facilitation of Recovery. The Application of Narrative Theories in a Group Therapy for Patients with Schizophrenia. DIEGESIS. Interdisciplinary E-Journal for Narrative Research 2018; 7: 1-18.

22. Kasperek-Zimowska B, Giguere M, Bednarek A, Żochowska A, Sawicka M. Positive psychotherapy for psychosis - a new approach in the rehabilitation of patients suffering from schizophrenia. Psychiatr Pol 2020; 54: 701-714.

23. Kasperek-Zimowska B, Bednarek A, Giguere M, Parnowska D, Żochowska A, Malewicz-Sawicka M. The impact of positive psychotherapy of psychoses on the subjective well-being of people suffering from chronic schizophrenia - Preliminary report. Counselling \& Psychotherapy Research 2021. DOI: https://doi.org/10.1002/ capr.12467.

24. Cechnicki A. W stronę psychoterapeutycznie zorientowanej psychiatrii środowiskowej - 30 lat doświadczeń krakowskich. Psychoterapia 2009; 3: 43-55.

25. Chądzyńska M, Meder J, Charzyńska K. Uczestnictwo w psychoedukacji osób chorych na schizofrenię - analiza zajęć z perspektywy pacjentów. Psychiatr Pol 2009; 43: 693-704.

26. Wing JK. Clinical concepts of schizophrenia. In: Wing JK (ed.). Schizophrenia: Towards a New Synthesis. London: Academic Press; 1978.

27. Liberman JA, Stroup TS, Perkins DO. Schizofrenia. The American Psychiatric Publishing; 2006.

28. Grzywa A. Oblicza psychozy. Lublin: Wydawnictwo Czelej; 2005.

29. Szabo J, Sipos M. Training the recognition of emotions based on bibliotherapy techniques. Psychiatr Danub 2018; 30 (Suppl 6): 380-383. 